\title{
A live art e o espectador em Das saborosas aventuras de Dom Quixote de la Mancha e seu fiel escudeiro Sancho Pança - um capítulo que poderia ter sido
}

Live art and the spectator in Das saborosas aventuras de Dom Quixote de la Mancha e seu fiel escudeiro Sancho Pança - um capítulo que poderia ter sido

Lúcia Helena Martins ${ }^{1}$ Anna Stegh Camati ${ }^{2}$ 


\section{Abstract}

A partir de conceitos de estética relacional e desfronterização entre arte e vida, este artigo pretende discutir sobre o papel ou os papéis do(s) espectador(es) no espetáculo de rua "Das Saborosas Aventuras de Dom Quixote de La Mancha e seu fiel escudeiro Sancho-Pança - um capítulo que poderia ter sido", do Grupo Teatro que Roda de Goiânia, que tem como pesquisa cênica o teatro como invasão do espaço da cidade.

Palavras-chave: Espectador; live-art; dramaturgia do espaço aesthetics and crossing of borders beween art and life, this article aims to discuss the role(s) of the spectator(s) in the street spectacle "Das Saborosas aventuras de Dom Quixote de la Mancha e seu fiel escudeiro Sancho Pança - um capítulo que poderia ter sido", by Grupo Teatro que Roda from Goiânia, whose object fesearch is the theatre of invasion of city sites

Keywords: Spectator; live art; spatia dramaturgy

ISSN: 1414.5731
Faculdade de Artes do Paraná. Profa Ms. Curitiba (PR). luhelena25@yahoo.com.br
${ }^{2}$ Centro Universitário Campos de Andrade (UNIANDRADE). Profa Dra. do $\underline{\text { com.br }}$

Ao contrário da aspiração das obras de arte moderna de formar realidades imaginárias ou utópicas, na contemporaneidade as artes "procuram constituir modos de existência ou modelos de ação dentro da realidade existente [...]" (Bourriaud, 2009, p.18). Para atingir esse objetivo, foi necessário deslocar as artes dos espaços monumentalizados para lugares, até então, não convencionais. Em face desse deslocamento, vários outros fatores formais, estéticos, éticos e políticos foram também transmutados. Dentre as questões que surgem a partir dessas novas perspectivas, destaca-se a reflexão filosófica sobre a aproximação entre arte/vida ou ficção/realidade. O visionário Antonin Artaud, já em 1938, ao se referir ao teatro de representação, psicológico e ficcional, afirmou: "Esse público que engole o falso pelo verdadeiro tem o senso do verdadeiro e sempre reage diante do verdadeiro quando colocado à sua frente. Não é, porém, em cena que se deve procurar esse verdadeiro hoje, mas na rua; e sempre que se oferecer à massa das ruas uma ocasião para mostrar sua dignidade humana, ela a mostrará" (Artaud,1984, p. 99).

Sabe-se que, desde quando surgiram as manifestações artísticas como performances, happenings e instalações a partir da década de 1960, muitos dos escritos de Artaud são difundidos, e a maneira de encarar a arte é transformada. Segundo Renato Cohen, que investiga a performance como linguagem: "A live-art é um movimento de ruptura que visa dessacralizar a arte, tirando-a de sua função meramente estética, elitista. A idéia é de resgatar a característica ritual da arte, tirando-a de 'espaços mortos', como museus, galerias, teatros, e colocando-a numa posição 'viva', modificadora" (Cohen, 2004, p. 38)

Quando as obras de arte são recolocadas em espaços urbanos, como invasoras destes espaços, tudo o que está ao entorno do espaço/tempo de tal manifestação é considerado arte, tanto os atores com seus figurinos e objetos, quanto os espectadores, os transeuntes do espaço, o espaço-cidade com suas ruas, carros, praças edifícios, a carga semântica de cada lugar, sua historicidade e as relações entre todos esses elementos. A performance, para Cohen, é uma expressão cênica que acontece no aqui-agora, e é uma arte de fronteira, pois rompe com a arte estabelecida de ate então, "tocando nos tênues limites que separavam vida e arte" (Cohen, 2004, p. 38)

Segundo Evill Rebouças, alguns encenadores utilizam a própria matéria em seu estado original, ao invés de reproduzirem uma cópia fotográfica do que existe na natureza. André Antoine, no início do século XX, insere objetos reais que carregam peso de uma materialidade em cena, para que o espectador se identifique com encenação, buscando um efeito realista para tal. Porém, com essa atitude, Antoine vai além do realismo, pois os objetos reais vão além da reprodução da aparência, trazendo para a cena a teatralidade do real. Foram dadas as bases para a constituição de modelos de ação dentro da realidade já existente. Quando um espetáculo/intervenção invade a rua, ele se apropria da teatralidade do real, de tal forma que a realidade tocada e transformada como obra de arte, que é a própria vida. Para Artaud, o teatro deve ser uma manifestação e o público estar envolvido de tal forma que pertença ao todo do evento/espetáculo/ritual. Nesse envolvimento que provém da configuração do espaço: "Será restabelecida uma comunicação direta entre o espectador e o espetáculo, entre o ator e espectador, pelo fato de o espectador, colocado no meio da ação, estar envolvido e atravessado pela ação" (Artaud, 1984, p. 123). 
Ao sair dos museus, das galerias, dos teatros em direção a outros espaços, outra relações são formadas. Esses espaços urbanos permitem a experiência da proximidade do encontro entre os seres humanos. O substrato dessas obras é veiculado pela intersubjetividade, cujo tema central - o encontro entre observador e obra -, faz com que haja uma concepção coletiva de sentidos de mundo. Segundo Nicolas Bourriaud (2009, p. 19) a arte relacional é "uma arte que toma como horizonte teórico a esfera das interações humanas e seu contexto social mais do que a afirmação de um espaço simbólico autônomo e privado". Nas artes relacionais, durante o evento existe a possibilidade de deslocamento, comentários e percepção imediatos, no espaço-tempo do evento. Então, a arte é criada e produzida nesse espaço-tempo a partir da sociabilidade presente no evento através de "'estados de encontro fortuito' proposto pela cidade" (Ibidem, p. 22). Se a arte é criada/produzida pelas relações que acontecem no momento desse encontro, o pape do espectador não é apenas o de um observador, ele passa também a ser ator, pois está inserido na obra, ao lado de ruas, carros e qualquer outro elemento que possa estabelecer alguma forma de sentido no momento. Mesmo se pensarmos nessa criação coletiva de sentido, cada espectador verá o espetáculo pelo seu ponto de vista e de acordo com o ângulo da posição espacial em que se encontra. Assim como os cenários em perspectiva do século XIX buscavam mostrar um ponto de vista e focar o olhar do espectador com essa saída dos palcos italianos para espaços abertos não convencionais, o olhar do espectador é polifônico, ou seja, ele pode olhar para onde quiser e escolher seu foco, fazendo com que o espectador que está ao lado de algum ator, faça parte da cena para o espectador que o olha. Bourriaud (Ibidem, p. 30) argumenta que o olhar do ser humano é quem cria as formas, e a partir daí elas passam a ser visíveis, ou seja, "elas desenvolvem-se umas a partir das outras". Cada indivíduo gera sua forma, conforme o seu comportamento e as suas relações com o outro: "Ela nasce nessa zona de contato em que o indivíduo se debate com o Outro para lhe impor aquilo que julga ser o seu 'ser'" (Ibidem)

Este encontro fortuito, citado acima, acontece num espaço e tempo que também dialoga com os indivíduos. Segundo Evill Rebouças, o local da encenação, suas características arquitetônicas, a atmosfera do local e a população de transeuntes interferem na dramaturgia do espetáculo. O fato de esses coletivos teatrais tomarem "como parte estrutural das narrativas um espaço real, carregado de carga histórica - elemento que incontestavelmente, tenciona e altera os discursos cênicos" (Rebouças, 2009, p. 100), torna o espetáculo um ato político, já que o artista lança um olhar questionador ao espectador. Há uma alteração na recepção do espetáculo que emerge da historicidade do espaço, pois a carga semântica interfere na percepção do espetáculo. Os temas abordados nos espetáculos acabam ganhando outras possibilidades de leitura em função da historicidade do espaço e da relação do público com ela.

Partindo dessas reflexões e questionamentos, no presente artigo será analisado - espetáculo Das saborosas aventuras de Dom Quixote de La Mancha e seu fiel escudeiro Sancho Pança - um capítulo que poderia ter sido, do Grupo Teatro que Roda de Goiânia ${ }^{3}$, que investiga o teatro como invasão do espaço da cidade. Ao falar sobre

a dramaturgia do espaço urbano e o teatro de invasão, André Carreira assevera que o teatro de rua ocupa o espaço urbano e ressignifica o sentido da rua. Enquanto o crescimento das cidades se dá pelo reforço das contradições sociais, o establishment tenta manter uma ordem, deixando certos espaços "limpos, organizados e preservados", para, através desse mecanismo, apagar suas contradições e articular "aquilo que podemos considerar como projetos de simulacros" (Carreira, 2005, p. 27). O teatro de invasão busca revelar essas contradições através dos seus procedimentos. Os não -lugares ${ }^{4}$ representam a auto-imagem do sistema capitalista, e a cidade é submetida a ampliar cada vez mais estes espaços de consumos (shoppings, lojas, condomínios fechados), em detrimento de lugares relacionais. E é a essas questões que o fenômeno teatral "de invasão" aspira resistir através de sua natureza vivencial, presencial e artesanal. Carreira acredita que na dramaturgia do espaço, ao tomar a cidade como texto, o teatro invasor rompe com a lógica da rua e os atores-invasores desorganizam seu fluxo construindo Lugares, "pois sugere aos cidadãos redefinir sua relação com os espaços da cidade implicando uma leitura da silhueta urbana como um prétexto no qual devem ser percebidas as contradições" (Ibidem, p. 28). O teatro que penetra no espaço público dialoga com os cidadãos que não optaram por assistir um fenômeno cênico, porém, têm o direito de escolher se assistem ou não ao evento. O espetáculo Das saborosas ${ }^{5}$, além da apropriação de elementos do romance Dom Quixote de Miguel de Cervantes, toma como texto a cidade:

[...] a ideia de repertório de usos do espaço urbano poderia interferir na construção na nossa percepção de dramaturgia. Nesta dramaturgia interfeririam as linhhas dos edificios, as tensões dos usuarios, o trânsito das pessoas e dos veículos e controle social do lugar público. As regras da cidade funcionam como material dramatúrgico na medida que constituem um texto que pode ser tomado como pré-texto para a construção da cena. A cidade então seria uma fala que pode ser re -interpretada pelo discurso cênico que ao mesmo tempo toma as estruturas físicas da cidade como suporte de sua construção espetacular (Ibidem, p. 30).

Segundo entrevista com o Grupo Teatro que Roda, a imagem geradora para este espetáculo foi um monumento localizado em uma das principais praças da cidade de Goiânia que remeteu-lhes o semblante de Dom Quixote. André Carreira foi convidado para dirigi-los e, após o aceite, foi iniciado o processo de concepção do espetáculo. Especulação da cidade, escolha dos locais de realização, observação dos locais, dos edifícios, ruas e fluxos de seu entorno, dos transeuntes, leitura de Dom Quixote de Cervantes, treino dos atores. Nestes espetáculos os atores lidam o tempo todo com o imprevisível, então eles trabalham com elementos de risco e devem estar prontos e abertos a toda forma de improvisação, mesmo que haja como base um roteiro cênico. Em relação ao roteiro utilizado nos espetáculos de dramaturgia do espaço, Carreira

Năo-lugar: termo utilizado por Marc Augé e citado por Carreira que signitf espaços que não conformam identidades senão que se oferecem como simplicam em compromissos com o próprio consumo. O não-lugar represent um lugar que não é mais que uma zona de consumo que opera sem construt nenhuma idéia de território ou de identidadde" (Carreira, 2005, p. 28). Dom Quixote de La Mancha e seu fiel escuderio Sancho Panşa - um capitu 
Propõe uma grande proximidade com a escritura do roteiro cinematográfico porque trabalha com imagens que constituem a matéria básica deste teatro, o melhor, desta dramaturgia da cidade. As imagens urbanas funcionam como elementos disparadores que propulsionariam a construção de sequências de ações dramáticas [...]. Disso nasceria a matriz para construção espetacular, de tal forma que o diálogo com estas estruturas constituiria a própria fala do espetáculo (Carreira, 2005, p. 31)

A fábula de Dom Quixote narra a história de um ingênuo homem de meia-idade que vive na zona rural e adora ler livros de cavalaria. Até que um dia, decide tornarse um cavaleiro andante e sair pelo mundo num velho pangaré batizado Rocinante, com o intuito de andar pelo mundo desfazendo injustiças, salvando donzelas, principalmente sua amada Dulcinéia, e combatendo gigantes e dragões. Conhece um lavrador chamado Sancho Pança que o acompanha pela promessa de ganhar uma ilha como pagamento de seu heroísmo. Dom Quixote vive sob a alucinação de que está vivendo no universo da cavalaria, vê pás de moinhos de vento e imagina que são gigantes com braços enormes, além de outros delírios. Com o desejo de combater as injustiças do mundo e homenagear sua dama, o personagem enfrenta situações perigosas e ridículas. De suas desventuras, restam-lhe as surras, as pedradas, os enganos. Em Das saborosas, o grupo reelabora alguns episódios do texto de Cervantes, "a fim de criar uma poesia urbana sobre o sonho, a loucura e o próprio sentido da cidade" 6 . O tema é o mesmo, porém ele é recontextualizado em centros urbanos contemporâneos. Dom Quixote, agora, é um homem engravatado remetendo a um homem de negócios, que desce de um prédio alto por uma corda gritando por Dulcinéia. Abandona seu terno e gravata e se faz cavaleiro com objetos do lixo. Sancho Pança é um catador de lixo que passa com seu carrinho e encontra Dom Quixote - este encontro parece uma coincidência, deixando dúvidas, a princípio entre os espectadores, se Sancho era realmente um transeunte ou se fazia parte do espetáculo. E o cavalo Rocinante é o próprio carrinho empurrado por Sancho. Vários outros elementos do romance são transpostos para a contemporaneidade, como o dragão que é constituído de uma colheitadeira, jovens punks são feiticeiros improvisados, estruturas de propaganda confundidas com gigantes, etc.

Como foi dito anteriormente, o teatro invasor busca mostrar as contradições do mundo capitalista de consumo da contemporaneidade. Em Das saborosas, po meio da forma, podemos observar uma subversão da ideia de realidade e imaginação, conteúdo do romance de Cervantes. Quando o performer/personagem Dom Quixote invade o fluxo organizado da cidade, luta contra os dragões que representam as injustiças do caminho da sua "suposta" imaginação, seria a revelação do que está por trás da aparência do mundo capitalista? Quantas pessoas são exploradas para manter este aparente fluxo limpo, feliz e organizado? Através deste espetáculo, abre-se um questionamento: O que é ilusão? O que é realidade? É o louco Quixote que vive de alucinações e sofre num mundo imaginário? Ou são os milhões de pessoas que vivem num mundo de ilusões, sofrendo para manter o fluxo da "felicidade" do ter, possuir e comprar, que acreditam ser real? A ilusão de um mundo organizado e feliz dos

${ }^{6}$ Frase retirada do programa do espetáculo. lugares capitalistas é invertida. Uma possível leitura é a entrada do performer/personagem que inicia o espetáculo descendo de rapel de prédios altos e de cabeça para baixo. Um mundo de cabeça para baixo, ou um mundo às avessas, quando é revelado o que está por trás da aparência.

Diferentemente da aspiração moderna e romântica de arte - como Dom Quixote - de mudar o mundo através da arte, esse espetáculo mostra um universo possível - e real, que pode ser outro (fazendo jus ao título: "um capítulo que poderia ter sido"). Percebe-se que, enquanto Dom Quixote pouco se relaciona com o público por estar imerso num universo ficcional, está a lutar num mundo à parte, com os monstros que procura combater; Sancho Pança - um catador de lixo que está à margem deste universo de empresários, funcionários públicos, etc. - se relaciona com o público real, construindo lugares de relação. Seria Sancho o próprio luga relacional que não é o shopping, nem os condomínios fechados, mas a própria rua. Pública? Sancho ao ser abordado por Quixote, quando este lhe faz a promessa de uma itha em troca de sua companhia, diz: "Pois vou embora. Prefiro Sancho sem nenhuma terra, que a Terra sem nenhum Sancho!" Sancho relaciona-se com as pessoas e revela a realidade, como, por exemplo, quando diz que a panela, que Quixote acredita ser o elmo de Manbrino, é apenas uma panela. Quixote acredita que é um objeto de valor, talvez como muitos consumidores que precisam ter o que não precisam porque acreditam que aquilo tem valor e é necessário. Mas ao mesmo tempo Quixote luta o tempo todo com esta (sua/nossa) realidade. Leitura marxista à parte a questão de metalinguagem em relação à história e função da arte também marca presença. Ambos os personagens Quixote e Sancho Pança trazem consigo o desejo de transformar o mundo num lugar melhor. Enquanto o romântico Dom Quixote luta para formar uma nova realidade utópica - como aspirava a arte moderna ao tentar mudar o mundo através de artes ficcionais -, Sancho constrói relações na realidade, sugerindo outras possibilidades de mundos, como aspira a arte contemporânea. Segundo Bourriaud, a arte contemporânea representa um interstício social: "um espaço de relações humanas que, mesmo inserido de maneira mais ou menos aberta e harmoniosa no sistema global, sugere outras possibilidades de troca além das vigentes nesse sistema" (Bourriaud, 2009, p. 22).

Paralelamente a essa interpretação metalinguística sobre ficção e realidade podemos também observar que a própria forma de dramaturgia do espaço comenta essa questão. Quando o espetáculo invade a rua, o espectador não sabe o que faz parte do espetáculo (o que é cena/ficção/representação) e o que é realidade (transeuntes/carros e objetos que estão ali por acaso), pois tudo o que está no entorno do acontecimento acaba fazendo parte do espetáculo e da criação de sentido do mesmo, já que os atores jogam o tempo todo com o imprevisível e com o que está acontecendo naquele tempo e espaço. $O$ ator, o texto, o público tem a mesma importância, e o acontecimento, no instante do espetáculo, é composto através do discurso do que se pode ver e vivenciar em cena. Segundo Rebouças $(2009$, p. 180) esses discursos podem ser articulados em situações "a partir da interação de todos os elementos cênicos explorados em uma representação: cartografia da cena, elementos visuais, sonoros, olfativos etc.". Os espectadores, assim como os atores, são colocados em situação de risco, visto que se relacionam, locomovem e atuam de 
acordo com os acontecimentos do aqui-agora. Para Rebouças, em espetáculos que utilizam o espaço da rua, ou outros espaços não convencionais em que o espectador se locomove durante a cena, o espectador não tem uma área fixa para apreciar a encenação, "está sempre em estado de alerta para os possíveis deslocamentos e ainda terá a possibilidade de optar por ficar afastado ou próximo da cena" (Ibidem, p. 152).

Em Das saborosas, o público se mistura com a cena, e a acompanha como se fizesse parte dela. De tal forma que há um limite muito tênue para o público distinguir se é apreciador ou personagem da ação. "A não distinção entre o espaço de encenação e plateia propicia um envolvimento com a ficção, porém alterado conforme o repertório do espectador" (Ibidem, 2009, p. 155). Como há um entrelaçamento entre o que é real e o que é ficção, e o local do acontecimento é a rua pública, ator e espectador correm riscos. Segundo Dionísio Bombinha (ator-criador de Das saborosas) em um dos eventos, durante uma luta de espadas que acontece entre Quixote e os feiticeiros, o performer realmente machucou a mão e o público teve que correr para não levar pancada, ao voar a espada, com a batida. Num outro dia, um espectador tenta segurar Sancho Pança, até que outros espectadores interferem. Todas essas manifestações e atitudes do público, no espaço - com toda a carga semântica que he é implícita -, compõem a dramaturgia e o sentido da obra. Parece que a utopia de "democratizar o teatro" é realizada com esta "dramaturgia do espaço", ou ainda, parece que a "utópica" concepção de Teatro do Futuro de Adolphe Appia tornou-se realidade, assim como através dos mundos possíveis gerados nesse espetáculo (interventores/ performances) talvez possa tornar-se real. Segundo Appia:

the chegaremos ao que se denominara "sala catedral do futuro", a qual, dentro de um espaço livre, vasto, transformável, acolherá as mais diversas manifestações de nossa vida social e artistica, e sera o lugar por excelência onde a arte dramatica florescera, com ou sem espectadores [...]. O termo representação tornar-se-á pouco a pouco um anacronismo. A arte dramática de amanhã será um ato social ao qual cada um dará a sua contribuição (Appia apud Cohen, 2004, p. 83).

Com essa afirmação de Appia de que a arte dramática florescerá "com ou sem espectadores", retornamos à questão do início do presente artigo, sobre o papel ou os papéis dos espectadores em Das saborosas.

Para Patrice Pavis, o olhar e o desejo do espectador - a partir da estética da recepção - "é que constituem a produção cênica, dando sentido à cena concebida como multiplicidade variável de enunciadores" (Pavis, 2005, p. 140). Mesmo sabendo dos tênues limites que separam as linguagens artísticas e suas classificações e nomenclaturas, esse espetáculo pode ser considerado, a partir da diversidade de recepção as quais proporciona: um longo espetáculo de encenação, uma instalação ${ }^{7}$ ou um ato social.

Pode-se ver Das saborosas como um longo espetáculo de encenação com uma fábula, que é a recriação de parte da temática do romance Dom Quixote de

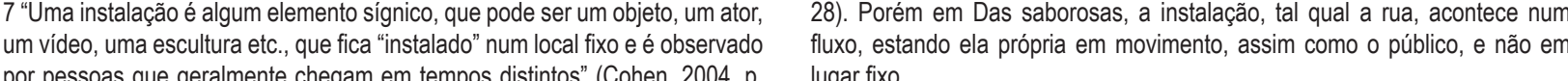

Cervantes, em que um número $x$ de espectadores iniciados ou não propõe-se a assistir e seguir, já que ele inicia num prédio e acontece em vários quarteirões em seu entorno, passando por ruas, praças, e em vários lugares ao mesmo tempo, pois os atores/performers estão espalhados pela cidade, e em alguns momentos eles se encontram, interagem, para em seguida, seguirem seus caminhos. Neste caso, é essencial lembrar que, mesmo que o sentido seja construído pelo olhar do espectador, "boa parte do trabalho do performer reside na sua capacidade de orientar a percepção do espectador até que ela coincida com a sua" (Glusberg, 2003, p. 88). Porém, o próprio performer necessita de grande jogo de cintura, já que a atuação no tempo presente faz com que ele tenha que conviver com as ambivalências do espaço real e do espaço ficcional, de forma imprevisível. Se vermos a manifestação como uma intervenção urbana ou instalação, partimos do ponto de vista daquele espectador/transeunte que passa por um dos locais do acontecimento e só vê uma ou outra cena/imagem. Em entrevista com o grupo, Dionísio Bombinha revela que cada cena foi criada para ser também plasticamente "uma espécie de instalação na cidade". Nesse caso, se a pessoa/ transeunte passa de ônibus ou a pé e vê no meio de um centro urbano uma colheitadeira com dez mulheres vestidas de noiva (Dulcinéias) sentadas, essa imagem é toda a obra para ela, e ainda assim, no instante dessa visão, a pessoa pode sair de seu fluxo rotineiro (mesmo que em pensamento) e refletir sobre a imagem com a qual se depara em seu caminho. Outro exemplo dessa natureza, nesse espetáculo, se configura quando aparece a imagem de um homem engravatado que desce por uma corda de ponta cabeça por um prédio, ou ainda, um homem engravatado com uma panela na cabeça discutindo com um catador de lixo. Que tipo de reflexões, sentimentos e sensações essas imagens podem engendrar? Que atitudes essas ações podem provocar?

Em todas essas formas de contato da manifestação com as pessoas, sejam elas transeuntes que apenas passam e olham, ou espectadores que sequem todo o roteiro, uma troca é realizada. Essas trocas, diferentemente das que estamos acostumados na contemporaneidade globalizada, não obedecem às leis do lucro. A imagem que o passageiro do ônibus vê não é um outdoor, mas por que ela está ali? As ruas, as praças, não são locais de compras, mas ali acontece uma relação, através da arte. Há outras possibilidades de troca, há outras possibilidades de mundo. "A arte é um estado de encontro fortuito" (Bourriaud, 2009, p. 22) em que os atores e os espectadores são todos performers atuantes ou não.

Então, o espectador, de todas as formas, é ao mesmo tempo atuante/ator, como construtor de sentido, pois, enquanto que, de um ponto de vista (ângulo no espaço), um espectador vê uma cena em que outro espectador interage ou não, este que é visto é também parte da obra e vice-versa. Cada movimento, cada relação é uma possibilidade de construção de sentido, e como há uma confusão entre o que é real e o que é teatro, em cada relação há uma possibilidade de um mundo possível. É a partir dessas relações que a forma se converte em rosto. "Toda a forma é um rosto que me olha porque ela me chama para dialogar" (Ibidem, p. 31). Como essa forma de dramaturgia nasce no e do espaço e tempo presente do acontecimento teatral, ela depende do público que se encontra no local. O deslocamento os comentários e as relações do espectador com ator, espectador com espectador 
espectador com o espaço urbano e espectador consigo mesmo são a própria dramaturgia. Não deixemos de lado a questão de que, se o ator/performer, apesar de seguir um roteiro, improvisar em grande parte do tempo devido aos acontecimentos do instante, ele também, em certa medida, é um espectador. Segundo Glusberg,

o performer atua como um observador. Na verdade ele observa sua própria produção, ocupando o duplo papel de protagonista e receptor do enunciado (a performance). Isso porque para a conversão do objeto em signo exige-se que quem o utilize simultaneamente o observe, a fim de provocar no espectador, mediante a re-codificação, uma atitude similar: a expectativa. $\mathrm{O}$ mecanismo da mimese, substituído ao nível da performance, é transportado, assim, para o público (Glusberg, 2003, p. 76).

As lacunas do imprevisível são preenchidas por todos. A dramaturgia do espaço é construída, através das relações entre as pessoas e as coisas que, por sua vez, acontecem ao lado da dramaturgia do espectador: é ao mesmo tempo o olho que olha e a forma que é olhada, sendo em sua totalidade, através desse encontro fortuito no espaço propositor e transformador de ações, a obra por si só da vida e da arte. Isso posto, se Appia dizia que a arte "florescerá com ou sem espectadores" é porque todos passam a ser atores/pessoas atuantes. E, se para atuar será preciso observar, então todos são também espectadores, numa intercalação do grande jogo das relações sociais que compõe o(s) mundo(s) possível (eis) da arte e da vida.

\section{Referências}

ARTAUD, Antonin. O teatro e seu Duplo. Trad. Teixeira Coelho. São Paulo: Max Limonad, 1984.

BOURRIAUD, Nicolas. Estética Relacional. Trad. Denise Bottmann. São Paulo: Martins Fontes, 2009.

CARREIRA, André. Dramaturgia do espaço urbano e o teatro "de invasão". In: Reflexões sobre a cena. (Orgs.). Sheila Diab Maluf e Ricardo Bigi de Aquino. Maceió: EDUFAL; Salvador: EDUFBA, 2005, p. 27-34.

COHEN, Renato. Performance como Linguagem. São Paulo: Perspectiva, 2004.

GLUSBERG, Jorge. A arte da Performance. São Paulo: Perspectiva, 2003.

PAVIS, Patrice. Dicionário de Teatro. Trad. J. Guinsburg e Maria Lúcia Pereira. São Paulo: Perspectiva, 2005.

REBOUÇAS, Evill. A Dramaturgia e a Encenação no Espaço Não-Convencional. São Paulo: UNESP, 2009. 